\title{
UPAYA PENGEMBANGAN KARAKTER PESERTA DIDIK MELALUI PENDIDIKAN JASMANI DAN OLAHRAGA
}

Susanto, M.Or

IAINTA

Februari 2021

\begin{abstract}
Abstrak
Upaya bagian dari usaha yang bertujuan untuk mencapai harapan yang diinginkan, dalam hal ini mengembangkan karakter pada peserta didik untuk mempunyai karakter baik. Karakter merupakan sesuatu yang dapat membedakan seseorang dengan orang lain. Karakter menjadi suatu identitas yang tidak dapat dituliskan seperti kartu pengenal. Dari kematangan karakter inilah kualitas hidup seorang pribadi diukur dengan pengamatan, perasaan dan penghargaan. Karakter ini tidak dapat diperoleh secara instan, tetapi melalui proses yang panjang, bila penerapan karakter ini baik, yang di contohkan oleh orang-orang yang memiliki karakter baik maka hasilnya akan tumbuh karakter yang kuat dalam diri seseorang. Banyak cara dan jalan untuk menanamkan karekter ini terutama melalui jalur pendidikan formal. Banyak orang yang beragumen bahwa generasi sekarang tidak memiliki karakter yang baik seperti yang diharapkan masyarakat dan orang tuanya, yang selalu dikecam atas rendahnya nilai-nilai tersebut adalah pendidikan. Pendidikan jasmani dan olahraga, merupakan salah satu mata pelajaran di sekolah wajib diajarkan dimana siswa selalu hormat kepada guru, taat terhadap peraturan, patuh terhadap instruksi, disiplin, tanggung jawab, peduli dengan teman, jujur, dan mau menerima kekalahan dari orang lain dan tidak berlaku curang yang kesemuanya itu aplikasi dari nilai-nilai pendidikan jasmani dan olahraga. Bagaimana kita mengajarkan karakter di sekolah melalui Pendidikan Jasmani dan olahraga. Dalam mengajarkan karakter sebaiknya lebih bersifat contoh,atau roll model, pepatah mengatakan bahwa tindakan lebih baik dari kata-kata, itulah Pendidikan jasmani dan olahraga
\end{abstract}

Kata Kunci : Upaya, Karakter, Pendidikan, Pendidikan Jasmani Dan Olahrag 


\section{PENDAHULUAN}

Melalui proses pembelajaran pendidikan jasmani dan olahraga di sekolah, merupakan salah satu upaya untuk mewujudkan manusia seutuhnya yang di selenggarakan di sekolah, baik dari jenjang pendidikan dasar sampai menengah. Pendidikan jasmani dan olahraga merupakan bagian integral dari pendidikan secara keseluruhan, bertujuan untuk mengembangkan aspek kebugaran jasmani, keterampilan gerak, keterampilan berpikir kritis, keterampilan sosial, penalaran, stabilitas emosional, moral, pola hidup sehat dan pengenalan lingkungan bersih. Pendidikan jasmani yang diajarkan di sekolah memiliki peranan yaitu memberikan kesempatan kepada peserta didik untuk terlibat dalam berbagai pengalaman belajar.

Pendidikan dalam semua jenjang dan mata pelajaran sebagai alat untuk menumbuhkan saling pengertian dan cinta damai pada para peserta didik dan masyarakatnya. Kemajuan teknologi informasi dan komunikasi yang sudah mencapai tahap yang sangat maju, telah merubah pola para remaja dan anakanak, pada gaya hidup yang semakin menjauh dari semangat perkembangan total, karena lebih mengutamakan keunggulan kecerdasan intelektual, dimana mengorbankan kepentingan keunggulan fisik dan moral individu. Budaya hidup hipo kinetic (kurang gerak) karenanya semakin kuat menggejala di kalangan anak-anak dan remaja, berkombinasi dengan semakin hilangnya ruang-ruang publik dan tugas kehidupan yang memerlukan upaya fisik yang keras. Dalam kondisi demikian, patutlah kita mempertanyakan kembali peranan dan fungsi pendidikan, khususnya pendidikan jasmani dan olahraga.

Karakter saat ini menjadi isu utama dalam pendidikan, selain menjadi bagian dari proses pembentukan akhlak anak bangsa, pendidikan karakter ini pun diharapkan mampu menjadi pondasi utama dalam mensukseskan Indonesia Emas 2025. Tujuan pendidikan saat ini adalah untuk pembentukan karakter yang terwujud dalam kesatuan esensial subyek dengan perilaku dan sikap hidup yang dimilikinya. Karakter merupakan sesuatu yang mengualifikasi seorang pribadi menjadi pribadi yang diharapkan baik. Karakter menjadi identitas yang mengatasi pengalaman kehidupan yang selalu berubah seiring dengan pergeseran gaya hidup. Dari kematangan karakter inilah kualitas seorang 
pribadi dapat diukur. Karakter ini tidak dapat diperoleh secara instan, tetapi melalui proses yang panjang dimulai sejak lahir, bila penerapan karakter ini baik, yang di contohkan oleh orang-orang yang memiliki karakter baik maka hasilnya akan tumbuh karakter yang kuat dalam diri seseorang. Banyak cara dan jalan untuk menanamkan karekter ini bagi anak terutama melalui jalur pendidikan formal. Dimana dalam lingkungan ini terdapat manusia-manusia dewasa yang telah memiliki karakter yang baik, manusia dimaksud adalah guru atau tenaga pendidik di jalur formal itu sendiri. Salah satu cara menanamkan karakter kepada anak didik adalah melalui pendidikan jasmani dan olahraga. Pendidik harus mampu mengimplemantasikan pendidikan karakter melalui mata pelajaran yang di ajarkannya kepada siswa dengan baik.

Pendidikan dan pembelajaran berbagai bidang ilmu di sekolah saat ini terkesan gersang (kering) dari keindahan hidup, karakter peserta didik diberikan dengan cara menghafal teori dan sangat minim praktek, terlalu abstrak dan kurang menyentuh value, karekter dan dimensi kemanusiaan dari bidang ilmu yang diajarkan. Seharusnya pendidikan dan pembelajaran sebagai bagian integral dari kebudayaan manusia dan oleh karenanya mempunyai karakteristik yang bersifat humanistis. Pendidikan dan pembelajaran yang demokratis dan humanistis adalah praktek pendidikan yang mambawa paserta didik nyaman dalam perbedaan (beda dalam kecerdasan, budaya, suku dan agama) kebebasan berfikir dan berkreasi, suasana pendidikan yang kolaboratif dan adaptif terhadap perubahan dengan orientasi pendidikan akan menghasilkan manusia terdidik yang memiliki karakter/soft skill, life skill dan survive dalam hidup.

Pendidikan karakter di Indonesia masih dipandang sebagai wacana dan belum menjadi bagian yang terintegrasi dalam pendidikan formal secara keseluruhan. Kemudian dilanjutkan dengan usaha-usaha yang dilakukan guru untuk merancang pendidikan karakter melalui konsep-konsep yang di mengerti oleh guru itu sendiri dengan merancang pendidikan karakter sebagai persiapan pembinaan anak didik, keluarga dan masyarakat. Usaha tersebut antara lain penetapan pendidikan karakter sebagai salah satu rencana strategis sekolah, perencanaan dan pelaksanaan program pendidikan. 


\section{PEMBAHASAN}

\section{Hakikat Karakter}

Karakter merupakan sekumpulan tata nilai yang menuju pada suatu system nilai yang melandasi pemikiran, sikap, dan perilaku yang ditampilkan seseorang. Kemdiknas (2010:11). Karakter sama dengan kepribadian. Kepribadian dianggap sebagai ciri, atau karakteristik, atau gaya, atau sifat khas dari diri seseorang yang bersumber dari bentukan-bentukan yang diterima dari lingkungan Kemdiknas (2010:11).

Karakter adalah sifat, budi pekerti, tabiat atau watak dari seseorang yang tumbuh berkembang dari sejak lahir hingga akhir hayatnya. Karakter ini akan dengan jelas menunjukkan jati diri seseorang seperti apa, meskipun tidak dapat di ukur secara pengalaman namun bisa dirasakan oleh orangorang di sekitarnya, apakah seseorang itu memiliki karakter yang baik atau tidak. Karakter merupakan sesuatu yang tidak terlihat tetapi terwujud dalam pikiran, persepsi, perilaku dan tindakan seseorang. Karakter menentukan kualitas dan nilai yang sesungguhnya dari seseorang. Pendidikan karakter mengajarkan kebiasaan cara berfikir dan bertindak yang membantu individu untuk hidup dan bekerja bersama sebagai keluarga dan masyarakat dan bernegara serta membantu mereka untuk membuat keputusan yang dapat dipertanggung jawabkan. Karakter yang diharapkan tercapai melalui jalur pendidikan formal, seperti yang terdapat dalam The Six Pillars of Character yang dikeluarkan oleh Character Counts Coalition (a project of the Joseph Institute of Ethics) adalah sebagai berikut :

a. Thustworthiness, karakter yang membuat seseorang menjadi berintegritas, jujur dan loyal.

b. Fairness, karakter yang membuat seseorang memiliki pemikiran terbuka serta tidak akan memanfaatkan orang.

c. Caring, bentuk karakter dari seseorang yang memiliki sikap peduli dan perhatian terhadap orang lain maupun kondisi social lingkungan sekitar.

d. Respect, betuk karakter yang membuat seseorang selalu menghargai dan menghormati orang lain.

e. Citizenship, bentuk karakter yang membuat seseorang sadar hukum dan peraturan serta peduli terhadap lingkungan alam. 
f. Responsibility, bentuk karakter seseorang agar bertanggung jawab, disiplin, dan selalu melakukan sesuatu dengan sebaik mungkin.

Dalam Undang-undang RI No. 20 tahun 2003 tantang Sistem Pendidikan Nasional pasal 3 disebutkan bahwa pendidikan nasional berfungsi mengembangkan kemampuan dan membentuk watak serta peradaban bangsa yang bermartabat dalam rangka mencerdaskan kehidupan bangsa, bertujuan untuk mengembangkan potensi peserta didik agar menjadi manusia yang beriman dan bertaqwa kepada Tuhan Yang Maha Esa, berakhlak mulia, sehat, berilmu, cakap, kreatif, mandiri dan menjadi warga Negara yang demokratis serta bertanggung jawab. Amanah UU Sisdiknas tahun 2003 ini bermaksud agar pendidikan tidak hanya membentuk insan yang cerdas, tetapi berkarakter, sehingga akan tercipta generasi yang tumbuh kembang dengan karakter yang bernafaskan nilai-nilai luhur Pancasila. Bukan manusia cerdas tetapi tidak berkarakter seperti para koruptor dan manusia-manusia penyelewang hukum, meraka merupakan manusia cerdas, namun tidak mempunyai karakter baik.

\section{Karakter Pesetra Didik}

Menurut Kemdiknas, (2010:7-10) karakteristik perkembangan pada tahap tersebut adalah sebagai berikut:

a) Pertumbuhan fisik, Alat indera sudah dapat berfungsi secara optimal dalam menunjang kemampuan sensoris. Pada usia 11 tahun beberapa anak perempuan sudah mendapatkan menstruasi sebagai tanda memasuki masa pubertas atau akil balik sedangkan pada anak laki-laki mengalami perubahan suara dan tanda kelamin sekunder. Dengan adanya perubahan ini, anak dapat mulai dikembangkan nilai-nilai. akhlak mulia seperti mandiri dan tanggung jawab untuk menjaga kebersihan dan kesehatan alat kelaminnya.

b) Ekspresi emosi, Pemahaman anak mengenai berbagai emosi lebih lengkap karena interaksi denganlingkungan semakin luas. Hal ini menstimulasi berbagai emosi dan memperkaya pengalaman batin anak. Perkembangan emosi primer (dasar) seperti senang, marah, takut, menjadi lebih kaya dengan berkembangnya emosi sekunder seperti bangga, curiga, cemburu, khawatir, menyesal, dan sebagainya. Nilai-nilai akhlak mulia yang dapat dikembangkan berkaitandengan perkembangan emosi ini antara lain jujur dalam 
mengutarakan sesuatu apa adanya, nilai santun untuk melatih anak berbicara dan bertindak sesuai tata karma, serta nilai pengendalian emosi, misalnya mengajarkan pada anak untuk tidak mudah marah atau sedih.

c) Perkembangan perspektif (wawasan), Pada tingkat awal di SD, anak-anak masih dalam tahap perspektif egosentrik, yang memiliki keterbatasan dalam memahamisesuatu dari sudut pandang orang lain. Setelah usia 10 tahun, mulai berkembang pemahaman mengenai perspektif dari berbagai sumber yang menjadi acuan. Pada tahap ini, nilai-nilai akhlak mulia seperti kasih sayang, kerjasama, toleransi, adil, dan cinta damai perlu dikembangkan. Hal ini ditujukan agar anak dapat menjalin hubungan yang harmonis dengan temanteman sebayanya, terlebih lagi bahwa penilaian teman sebaya mulai menjadi hal yang cukup penting bagi anak-anak usia sekolah dasar.

d) Identitas diri, Dengan semakin luasnya lingkup interaksi dan kesempatan berpartisipasi dalam berbagai aktivitas di sekolah maupun keluarga, maka berkembang kesadaran diri dalam berbagai dimensi. Pemahaman dan konsep mengenai diri sendiri merupakan dasar bagi pembentukan identitas diri yang positif, bukan suatu kekaburan identitas diri. Hal ini berkaitan dengan nilai akhlak percaya diri yang berkaitan dengan usaha untuk mendorong anak untuk berani menampilkan kemampuannya serta tidak mudah terpengaruh dengan perilaku teman-teman yang tidak baik.

e) Pembentukan individualisme dan peran gender, Tumbuh dan berkembang bersama kelompok sebaya dari jenis kelamin yang sama maupun berbeda akan membangun kesadaran yang positif mengenai peran gender, yaitu saling menerima dan menghargai peran gender masing-masing. Berkaitan dengan perkembangan tersebut, maka perlu dikembangkan nilai akhlak seperti toleransi, kasih sayang dan rendah hati.

f) Konsep mengenai moral, Intensitas interaksi denganteman sebaya maupun guru merupakan faktor penunjang perkembangan konsep moral. Tingkat selanjutnya adalah moralitas autonomous, yaitu pemahaman bahwa nilai moral tergantung pada intensi (kesengajaan atau ketidak sengajaan melakukan sesuatu) suatu perilaku. Pada tingkat ini anak sudah dapat memandang bahwa hukuman adalah konsekuensi perilaku berdasarkan intensi. Berkaitan dengan perkembangan moral seperti toleransi dan berpikir positif, agar anak dapat lebih bijak dalam memandang baik buruknya suatu perbuatan. 
Agar peserta didik dapat berprestasi tinggi dibutuhkan beberapa karakter dasar yang harus dimiliki di antaranya adalah sebagai berikut: spiritualitas (KeTuhanan), kepekaan sosial, ulet, kerja keras, disiplin, bertanggung jawab, berwawasan luas, optimis, dan jiwa nasionalisme. Karakter dasar tersebut jika dapat dimiliki peserta didik secara utuh maka akan dapat menjadi individu yang matang yang mampu menghadapi segala tantangan yang selalu berubah. Individu yang matang baik jasmani maupun rohani tidak terbentuk dalam waktu sesaat namun memerlukan proses yang panjang dan rumit.

Spiritualitas (Ketuhanan), keimanan yang kuat sangat penting bagi diri peserta didik sebab sumber kebaikan adalah aturan agama. Dengan rasa KeTuhanan yang tinggi ini menjadikan peserta didik merasa dekat dengan Tuhan sehingga segala gerak-gerik, tingkah laku, dan ucapan merasa selalu diawasi oleh Tuhan. Hukum agama berupa pahala, dosa, boleh, dan makruh merupakan indikator tata laku orang yang beriman.

Keimanan yang kuat juga dapat menjadikan peserta didik memiliki jiwa rendah hati (tawaduk), dan tidak terlalu percaya diri (over confidence) sehingga meremehkan kemampuan orang lain. Spiritualitas yang kuat pada diri peserta didik dapat menciptakan motivasi instrinsik yang luar biasa, karena segala yang dilakukan dalam kiprahnya sebagai seorang pelajar diyakini sebagai ibadah dan mencari keridhoan Tuhan. Mu'awijah r.a berkata Rasulullah s.a.w bersabda: Siapa yang dikehendaki oleh Allah akan mendapat kebaikan, maka dipandaikan dalam agama. (H.R. Buchary, Muslim), serta hadist-hadist lain yang memerintahkan untuk menuntut ilmu. Bagi seorang mu'min sejati perintah Allah dalam Alqur'an dan perintah Rosul dalam hadist diyakini sebagai kewajiban yang harus dilakukan, demikian juga perintah tentang anjuran untuk mencari ilmu. Oleh karena itu kegiatan belajar apabila didasari oleh motivasi ibadah maka seberat apapun aktivitas tersebut akan dapat dilakukan secara ikhlas.

Kepekaan sosial adalah ketajaman (sensitivity) rasa dalam interaksinya sesama manusia. Kepekaan sosial memunculkan sifat empati, toleransi, tepa selira, kerja sama, rela menolong, gotong royong, dan sebagainya. Keimanan yang kuat akan menumbuh kembangkan kepekaan sosial karena setiap agama pasti mengajarkan agar berbuat baik kepada sesama manusia sebagai makhluk Tuhan. Munculnya sikap anarkis, memaksakan kehendak, premanisme, vandalisme, 
egoistis, serakah, tamak, dan sikap menang sendiri disebabkan terkikisnya nilai kepekaan sosial ini.

Ulet dan kerja keras adalah keadaan jiwa dan raga untuk mencapai citacita dengan sepenuh kemampuan, tabah menghadapi hambatan atau kesulitan, serta kreatif mencari solusi untuk pemecahan masalah. Sikap ulet dan kerja keras harus ditanamkan kepada peserta didik. Peserta didik yang memiliki sikap ini kelak setelah dewasa akan selalu dapat menyesuaikan keadaan yang mungkin serba sulit. Realita di masyarakat menunjukkan bahwa kehidupan penuh dengan persaingan/kompetisi, dan hanya manusia yang memiliki daya kompetitif tinggi yang menang dalam persaingan.

Disiplin adalah sikap yang diwujudkan dalam perilaku yang dilandasi rasa keikhlasan untuk menaati ketentuan, norma, atau peraturan yang telah disepakati sesuai dengan waktu yang telah ditentukan. Sikap disiplin bagi peserta didik sangat besar perannya dalam pencapaian prestasi. Sikap disiplin bagi peserta didik yang harus dilakukan antara lain, adalah ketaatan: waktu belajar, waktu berlatih, waktu beristirahat, dan perilaku yang dilarang pendidik yang dapat menurunkan prestasi belajar. Sikap disiplin ini akan dapat melahirkan perilaku yang istikomah dalam mempertahankan prestasi belajar.

Bertanggungjawab adalah sikap bersungguh-sungguh dalam menerima tugas dan kemauan yang kuat untuk mencurahan segala kemampuan dan pikiran demi tercapainya tugas yang dipikulnya. Peserta didik yang memiliki rasa tanggung jawab yang tinggi akan mencurahkan segala kemampuan dan pikiran yang dimilikinya demi pencapaian prestasi tertinggi, yang mana hal ini dapat mengharumkan nama diri sendiri, sekolah, orang tua, masyarakat, bangsa dan negara yang memberi tanggung jawab. Dengan sikap bertanggungjawab ini peserta didik akan memiliki komitmen yang lurus, dan idealisme yang mantap terhadap sesuatu yang diyakini.

Optimis adalah keyakinan disertai rasa penuh harapan bahwa segala citacita akan dapat diraih apabila dilakukan dengan usaha dan doa yang sungguhsungguh serta semangat pantang menyerah. Usaha yang dilakukan peserta didik meliputi usaha lahir dan usaha batin. Usaha lahir berupa belajar dan berlatih keras, peningkatan kualitas gizi yang dikonsumsi, dan peningkatan motivasi berprestasi 
terus-menerus. Sedang usaha batin adalah rajin berdoa, minta didoakan oleh teman atau saudara, tawakal, dan pemenuhan kebutuhan non teknik lainnya. Sikap optimis ini akan dapat mendorong peserta didik memiliki semangat pantang menyerah, terhindar dari sifat cengeng, dan memiliki banyak cara untuk meraih sukses.

Nasionalisme adalah sikap merasa menjadi warga suatu bangsa dan bangga dengan bangsa yang dimiliki. Peserta didik harus ditanamkan kesadaran yang dalam akan arti nasionalisme ini karena di negara ini dilahirkan, dibesarkan, mencari penghidupan, mati dan dikuburkan. Pendidik agar berusaha keras menanamkan kesadaran jiwa nasionalisme ini kepada peserta didiknya, dan mencegah rasa rendah diri menjadi bangsa Indonesia, sebaliknya bangga memakai atribut bangsa lain. Peserta didik dengan Jiwa nasionalisme yang tinggi memungkinkan untuk memiliki daya juang yang luar biasa dalam meraih prestasi di iven-iven internasional. Prestasi yang tinggi di kancah internasional akan dapat mengangkat citra bangsa dan kehormatan negara Indonesia.

\section{Pendidikan Jasmani dan Olahraga}

Pendidikan jasmani merupakan salah satu proses pendidikan yang memanfaatkan aktivitas fisik untuk menghasilkan perubahan secara holistik seperti kualitas individu, baik dalam hal fisik, mental, serta emosional. Pendidikan jasmani memperlakukan anak sebagai sebuah kesatuan utuh, mahluk total, dari pada hanya menganggapnya sebagai seseorang yang terpisah kualitas fisik dan mentalnya. Pendidikan jasmani berkaitan dengan hubungan antara gerak manusia dan pendidikan lainnya, hubungan dari perkembangan tubuh fisik dengan pikiran dan jiwanya.

Menurut Husdarta (2011: 143), pendidikan jasmani ialah suatu proses pembelajaran melalui aktivitas jasmani yang didesain untuk meningkatkan kebugaran jasmani, mengembangkan keterampilan motorik, pengetahuan dan perilaku hidup sehat dan aktif, sikap sportif, dan kecerdasan emosi. Lingkungan belajar yang diatur secara struktur dan sistematis untuk meningkatkan pertumbuhan dan perkembangan menyeluruh, seperti jasmani, psikomotor, kognitif, dan afektif setiap siswa.

Sedangkan Achmad (2012: 4) mendefinisikan pendidikan jasmani dan Olahraga adalah proses pendidikan melalui aktivitas jasmani dan olahraga yang 
terpilih untuk mencapai tujuan pendidikan. Dari pengertian ini mengukuhkan bahwa pendidikan jasmani merupakan bagian tak terpisahkan dari pendidikan umum. Tujuannya adalah untuk membantu anak agar tumbuh dan berkembang secara wajar sesuai dengan tujuan pendidikan nasional, yaitu menjadi manusia Indonesia seutuhnya.

Melakukan kegiatan olahraga secara teratur merupakan alternatif yang efektif dan aman dalam upaya meningkatkan dan mempertahankan kebugaran dan kesehatan (Supriyanto, 2002: 52). Pendidikan jasmani merupakan salah satu cara untuk memperoleh kebugaran di sekolah. Menurut Harsustik (Susworo, 2008: 12) pendidikan jasmani merupakan bagian integral dari pendidikan keseluruhan yang bertujuan meningkatkan individu secara organik, intelektual dan emosional melalui aktivitas jasmani. Sukintaka (Susworo, 2008: 13) pendidikan jasmani merupakan proses interaksi antara peserta didik dengan lingkungan melalui aktivitas jasmani yang disusun secara sistematis untuk menuju manusia Indonesia seutuhnya. Pendidikan jasmani, olahraga, dan kesehatan merupakan media untuk mendorong pertumbuhan fisik, perkembangan psikis, keterampilan motorik, pengetahuan dan penalaran, penghayatan nilai-nilai (sikap-mental-emosional-sportivitas-spiritualsosial), serta pembiasaan pola hidup sehat yang bermuara untuk merangsang pertumbuhan dan perkembangan kualitas fisik dan psikis yang seimbang.

Menurut Rusli Lutan (2000: 1) pendidikan jasmani merupakan wahana untuk mendidik anak dan merupakan alat untuk membina anak agar mampu membuat keputusan terbaik tentang aktivitas jasmani yang dilakukan dan menjalani pola hidup sehat sepanjang hayatnya. Menurut Patusuri (2012: 1) pendidikan jasmani dan olah raga merupakan prooses pendidikan yang memanfaatkan aktivitas fisik dan olahraga untuk menghasilkan perubahan holistic dalam kualitas individu, baik dalam hal fisik, mental dan emosional.

Pendidikan jasmani mempunyai tujuan pendidikan sebagai, (1) perkembangan organ-organ tubuh untuk meningkatkan kesehatan dan kebugaran jasmani, (2) perkembangan neuro muskuler, (3) perkembangan mental emosional, perkembangan social, dan (5) perkembangan intelektual. Tujuan dari kegiatan aktivitas olahraga dan pendidikan jasmani terletak dalam peranannya sebagai wadah unik penyempurnaan watak, dan sebagai wahana untuk memiliki dan membentuk kepribadian yang kuat, watak yang baik dan sifat yang mulia, hanya 
orang-orang yang memiliki kebajikan moral seperti inilah yang akan menjadi warga masyarakat yang berguna.

Pendidikan jasmani hakikatnya ialah proses pendidikan yang memanfaatkan aktivitas fisik untuk menghasilkan perubahan holistik dalam kualitas individu, baik dalam hal fisik, mental, serta emosional. Pendidikan jasmani memperlakukan anak sebagai sebuah kesatuan utuh, mahluk total, daripada hanya menganggapnya sebagai seseorang yang terpisah kualitas fisik dan mentalnya. Dari kenyataannya, pendidikan jasmani yaitu suatu bidang kajian yang sangat luas. Titiper fokus hatiannya adalah peningkatan gerak manusia. Lebih khusus lagi, pendidikan jasmani berkaitan dengan hubungan antara gerak manusia dan wilayah pendidikan lainnya, hubungan dari perkembangan tubuh-fisik dengan pikiran dan jiwanya.

\section{Karakter dalam Pendidikan Jasmani dan Olahraga}

Pembangunan karakter dilakukan dengan pendekatan sistematik dan integrative dengan melibatkan keluarga, satuan pendidikan, pemerintah, masyarakat sipil, media massa, dunia usaha dan industry. Namun pendekatan yang sangat mungkin dan akan mencapai semua lapisan adalah melalui satuan pendidikan karena semua orang membutuhkan pendidikan. Dalam dunia pendidikan pada setiap mata pelajaran baik disekolah maupun di perguruan tinggi pendidikan karakter selalu di tanamkan kepada peserta didik, demikian juga dengan mata pelajaran pendidikan jasmani dan olahraga.

Pendidikan Jasmani merupakan bagian integral dari pendidikan secara keseluruhan, sehingga pendidikan jasmani memiliki arti yang cukup representatif dalam mengembangkan manusia yang berkarakter dalam persiapannya menuju manusia Indonesia seutuhnya. Pendidikan jasmani di Indonesia memiliki tujuan kepada keselarasan antara tubuhnya dan perkembangan jiwa, dan merupakan suatu usaha untuk membuat bangsa indonesia yang sehat lahir dan batin, diberikan kepada segala jenis sekolah. (UU no 4 tahun 1950, tentang dasar-dasar pendidikan dan pengajaran di sekolah bab IV pasal 9). Pendidikan jasmani mempunyai tujuan pendidikan sebagai ;

a) Perkembangan organ-organ tubuh untuk meningkatkan kesehatan dan kebugaran jasmani,

b) Perkembangan neuro muskuler,

c) Perkembangan mental emosional, 
d) Perkembangan sosial dan

e) Perkembangan intelektual.

Tujuan akhir pendidikan jasmani dan olahraga terletak dalam peranannya sebagai wadah unik penyempurnaan watak, dan sebagai wahana untuk memiliki dan membentuk kepribadian yang kuat, watak yang baik dan sifat yang mulia, Uraian di atas memperjelas bahwa pendidikan jasmani dan olahraga merupakan 'alat' pendidikan, sekaligus pembudayaan watak yang kita kenal sekarang dengan istilah karakter.

Bagaimana kita mengajarkan karakter di sekolah melalui Pendidikan Jasmani dan olahraga. Dalam mengajarkan karakter sebaiknya lebih bersifat contoh, pepatah mengatakan bahwa tindakan lebih baik dari kata-kata. Lebih lanjut dalam tulisan ini di kemukakan beberapa nilai karakter dalam pendidikan jasmani dan olahraga yang termaktup juga dalam The Six Pillars of Character seperti yang telah di kemukakan diatas yaitu :

a) Jujur, dapat dipercaya.

Kata jujur digunakan untuk menunjukkan bahwa seseorang mengatakan atau melakukan sesuatu tanpa ada mengubah dari realita yang sebenarnya. Sesuatu atau fenomena yang di hadapi dapat berada pada diri sendiri atau di luar diri sendiri. Bagi seorang guru dan siswa, memperoleh kepercayaan salah satunya sangat ditentukan oleh kejujuran dalam mengatakan sesuatu apa adanya. Seorang guru Penjas dengan jiwa yang matang berani mengatakan bahwa ia tidak dapat mendemonstrasikan (mencontohkan) suatu gerak keterampilan senam lantai (handspring) ia hanya mampu menjelaskan cara melakukannya, tanpa perasaan bahwa prestisenya akan jatuh di depan siswanya. Seorang siswa dengan jujur mengatakan ia meniru pekerjaan temannya karena kesulitan dalam penyelesaiannya. Siswa tidak curang saat ujian teori, dengan menyontek/ meniru jawaban teman atau cacatan. Siswa tidak bertindak curang saat praktek olahraga bola basket dengan mengatakan pointnya bertambah padahal belum terjadi pemambahan angka, dan memprotes wasitnya. Kejujuran dan kebajikan selalu terkait dengan kesan terpercaya, dan terpercaya selalu terkait dengan kesan tidak berdusta, menipu atau memperdaya. Hal ini terwujud dalam tindak dan perkataan. Semua pihak percaya bahwa wasit dapat mempertaruhkan integritasnya dengan membuat keputusan yang fair. Ia terpercaya karena keputusannya mencerminkan 
kejujuran. Kejujuran ini sangat penting, karena jika tidak ada kejujuran dalam diri seseorang, maka tidak hanya orang disekitarnya saja yang semakin rusak, melainkan seluruh aspek-aspek lain juga bobrok, yang mengakibatkan bangsa semakin hancur. Oleh sebab itu pembentukan karekter jujur adalah sangat penting ditanamkan bagi peserta didik melalui pendidikan jasmani dan olahraga dengan melalui iyal-iyal :" curang, no way" jujur, yes", dsb nya. Guru harus dapat meyakinkan siswanya bahwa perbuatan tidak jujur adalah perbuatan yang memalukan dan merugikan.

b) Berlaku Hormat (Respect)

Hormat, bukan berarti menghormati seperti kita hormat kepada bendera merah putih pada setiap upacara bendera atau menghormati Pembina upacara pada saat perayaan hari-hari besar kenegaraan. Namun hormat disini maksudnya adalah sopan dan menghargai orang lain. Dalam pengamatan sehari-hari sikap hormat itu dapat dilihat berdasarkan bahasa tubuh seseorang dari cara mereka bersalaman dengan orang yang lebih di tuakan apalagi kepada orang tua atau guru. Anak atau siswa selalu meletakkan tangan guru kekeningnya. Sikap hormat ini juga tercermin dari keakraban antara siswa yang berbeda budaya dan agama. Bukan hanya dengan bersalaman, dengan tersenyum dan sedikit menundukkan kepala juga sudah tercermin bahwa berlaku hormat itu telah tertanam dalam diri seseorang. Perilaku hormat ini juga penting dalam menjaga kestabilan hubungan baik dengan seseorang, bayangkan jika seorang pemain dalam suatu pertandingan cabang olahraga, tidak menghargai keputusan wasit dimana wasit telah berlaku jujur dan adil atau tidak menghormati keputusan pelatihnya ketika menentukan pemain inti atau cadangan maka akan terjadi perselisihan diantara mereka dan hasilnya akan terjadi perpecahan bahkan perkelahian.

c) Tanggung Jawab (Responsibility)

Tanggung jawab berarti berani menanggung resiko atas perbuatan yang dilakukan. Seorang siswa yang bertanggung jawab berarti ia telah menunjukkan perilaku yang benar, melakukan yang terbaik, disiplin dan menghadapi resiko dari perbuatannya. Pada kalangan siswa karakter bertanggung jawab ini dapat dikembangkan dalam mata pelajaran pendidikan jasmani dan olahraga dan kegiatan ekstrakurikuler. Siswa dibiasakan memakai pakaian olahraga ketika praktek lapangan, mengumpulkan tugas tepat waktu, 
masuk dan keluar kelas tepat waktu, membereskan dan merapikan peralatan olahraga bersama-sama yang dipergunakan saat praktek. Mengumpulkan dan membariskan teman-teman sekelas secara bergantian juga akan menanamkan rasa tanggung jawab bagi anak. Tanggung jawab merupakan nilai moral penting dalam kehidupan bermasyarakat. Tanggung jawab ini adalah pertanggungan perbuatan sendiri. Seorang atlet harus bertanggung jawab kepada timnya, pelatihnya dan kepada permainan itu sendiri. Tanggung jawab ini merupakan nilai moral terpenting dalam olahraga.

d) Kepedulian (Caring)

Salah satu karakter yang penting untuk dikembangkan dan ditanamkan bagi anak didik adalah kepedulian atau perhatian karena dalam kepedulian ini tertanam rasa kasih sayang dan senang membantu orang lain. Rasa perduli terhadap sesama teman dapat ditanamkan dengan cara mengajak anak-anak sekelasnya mengunjungi/ menjenguk salah satu siswa yang sakit. Diingatkan agar saling membantu dalam mengerjakan tugas sekolah, terutama bagi siswa yang mengalami kesulitan belajar. Membatu teman yang ditugaskan guru cukup dengan memberikan hukuman berupa tendangan bebas.

e) Kedamaian.

Kedamaian mengandung pengertian : a). tidak akan menganiaya, b). Mencegah penganiayaan, c). menghilangkan penganiayaan, dan d). berbuat baik. Bayangkan bila ada guru yang menyakiti anak didiknya, kemungkinan anak tersebut tidak akan mau lagi kesekolah untuk belajar, ia lebih memilih dirumah atau yang lebuh buruknya lagi, anak berangkat dari rumah tetapi tidak masuk ke sekolah, malah pergi ketempat-tempat yang tidak sepantasnya di jam-jam sekolah, hal ini disebabkan karena anak tidak merasa nyaman dan damai disekolah. Seorang anak yang merasa damai dan nyaman bersama temannya, mereka akan selalu bersama dan perselisihan itu kecil kemungkinan terjadi, mereka saling mengunjungi, saling mengiangatkan dan saling membantu, bayangkan bila hal ini terjadi dalam lingkub yang lebih besar dan terjadi dalam segala aspek, maka damainya kehidupan ini.

f) Keadilan.

Keadilan sangat sulit diterapkan dalam kehidupan sehari-hari. Umumnya manusia akan berlaku adil kepada orang lain, namun menuntut lebih untuk dirinya. Lebih buruk lagi, mengurangi keadilan pada orang lain, dan 
menambah jumlah pada diri sendiri. Seorang guru pendidikan jasmani dan olahraga harus mampu bersikap adil kepada anak-anak didiknya, terutama dalam memberikan penghargaan atau penilaian, jangan sampai anak yang kurang mampu dalam psikomotoriknya lebih baik penghargaan atau nilai yang diberikan dari pada anak yang lebih baik darinya, hal ini akan menimbulkan rasa diperlakukan tidak adil terhadap dirinya. Kemungkinan hal ini juga akan dilakukannya dikemudian hari. Keadilan ada dalam beberapa bentuk ; distributif, prosedural, retributif dan kompensasi. Keadilan distributif berarti keadilan yang mencakup pembagian keuntungan dan beban kerja secara relatif. Keadilan prosedural mencakup persepsi terhadap prosedur yang dinilai sportif atau fair dalam menentukan hasil. Keadilan retributif mencakup persepsi yang fair sehubungan dengan hukuman yang dijatuhkan bagi pelanggar peraturan yang berlaku. Keadilan kompensasi mencakup persepsi mengenai kebaikan atau keuntungan yang diperoleh penderita atau yang diderita pada waktu sebelumnya. Dalam dunia olahraga keadilan ini sangat penting terutama bagi seorang yang berperan sebagai pengadil (wasit). Seorang wasit bila ragu memutuskan apakah pemain penyerang berada pada posisi off-side dalam sepakbola, ia minta pendapat penjaga garis. Semua pemain penyerang akan protes, meskipun akhirnya harus dapat menerima, jika misalnya wasit dalam kasus lainnya memberikan hukuman tendangan penalti akibat pemain bertahan menyentuh bola dengan tanganya, atau sengaja menangkap bola di daerah penalti.

\section{PENTUP}

Semua pendidik berharap ingin anak didiknya memiliki karakter yang kuat, hal ini tentunya mengandung harapan yang besar bagi perubahan karakter bangsa secara , menyeluruh. Perubahan ini tidak akan terjadi dengan cepat dan instan, tetapi melalui proses yang cukup panjang. Oleh karena itu tenaga pendidik harus selalu sabar, mampu dan berupaya keras menanamkan karakter itu kepada anak-anak didik. Tentu hal ini harus dimulai dari diri kita sendiri sebagai pendidik, karena kitalah yang akan ditiru oleh mereka. Apa yang kita berikan hari ini akan membuahkan hasil tidak jauh berbeda dihari yang akan datang.

Pada kesempatan ini penulis mencoba mengajukan beberapa konsep tentang pendidikan karakterdalam pendidikan jasmani dan olahraga berdasarkan uraian diatas, 


\section{Scientific Archive Personal Journal}

No.X001/28.02.21

Online at http://sapj-journal.blogspot.com

yaitu Pemahaman nilai-nilai pendidikan jasmani dan olaharaga seperti tanggung jawab, kejujuran, kepedulain, kedamaian, rasa keadilan, dan berlaku hormat. Dengan nilainilai tersebut diharapkan pesertadidik mempunyai karakter yang baik demi kemajuan pendidikan indonesia secara umum.

\section{PUSTAKA}

Asih Menanti, dkk. (2012). Pendidikan Karakter. Medan. Unimed

Lubis, Johansyah. (2011). Etika dan Moral Dalam Penddikan Jasmani. Jakarta. Artikel.

Rusli Lutan (ed)., (2001). Olahraga dan Etika Fair Play. Direktorat Pemberdayaan IPTEK Olahraga, Dirjen OR, Depdiknas, Jakarta: CV. Berdua Satutujuan.

Sinaga, Bornok. (2012). Konsep dan Implementasi Karakter Intelektual. Medan. Artikel Depdikbud. Dirjen Pendidikan Dasar dan Menengah. Bagian Proyek Penataran Guru SLTP Setara D-III.

Eka Izzaty, Rita. dkk. 2008. Perkembangan Peserta Didik. UNY Press. Yogyakarta.

Erfayliana, Yudesta. 2014. Pengembangan Model Pembelajaran Sepak Bola melalui Permainan Selat Ball Bagi Siswa Sekolah Dasar. Tesis. UNNES. Semarang.

Husdarta dan M. Yudha Saputra. 2000. Belajar dan Pembelajaran. Depdikbud. Dirjen Pendidikan Dasar dan Menengah. Bagian Proyek Penataran Guru SLTP Setara D-III. Jakarta.

Kemdiknas. (2010). Pedoman Pembinaan Akhlak Mulia Siswa Melalui Kegiatan Ekstrakurikuler, Jakarta: Kemdiknas.

Sisiwoyo, Dwi. dkk. 2008. Ilmu Pendidikan. UNY Press. Yogyakarata.

Siswanto, Djoni. 2003. Peran Guru Pendidikan Jasmani dan Kesehatan Sekolah Dasar Inti dalam Pembinaan Olahraga Usia Dini di Sekolah Dasar Kecamatan Banyumanik Kota Semarang. Tesis. UNNES. Semarang. 